\title{
The impact of muscle tone on the development of auditory perception - research orientation
}

\author{
WIOLETTA PAWLUKOWSKA ${ }^{1, A-F}$, KATARZYNA SIWCZAK ${ }^{2, A}$ A B, F, ALEKSANDRA SZYLIŃSKA ${ }^{3, c, ~ D, ~ E, ~}$ \\ AGNIESZKA TUROŃ ${ }^{3, A, E, F}$, IWONA ROTTER ${ }^{1, c-F}$ \\ ${ }^{1}$ Department of Medical Rehabilitation, Clinic of Neurology, Pomeranian Medical University, Szczecin, Poland \\ ${ }^{2}$ Student at Physiotherapy Department of Pomeranian Medical University, Szczecin, Poland \\ ${ }^{3}$ Department of Medical Rehabilitation, Pomeranian Medical University, Szczecin, Poland
}

A - Study Design, B - Data Collection, C - Statistical Analysis, D - Data Interpretation, E - Manuscript Preparation, F - Literature Search, $\mathbf{G}$ - Funds Collection

Summary Background. Our brain accomplishes the remarkable feat of processing a continuous stream of incoming sensory information at an astonishing speed. Auditory perception is a complex process of organizing sensory information received by the brain through the auditory system.

Objectives. Auditory perception in children affected with pathological muscle tone, including a comparison of spatial localization in children without tonus abnormalities; the influence of age and gender on auditory reactions in children with and without pathological muscle tone.

Material and methods. The studied group consisted of $29(100 \%)$ subjects, made up of 8 females (28\%) and 21 males (72\%), all afflicted with tonus pathology. The children were aged between 30 and 116 weeks (mean age 44.6 weeks) and divided into subgroups according to their levels of motor development. The control group was composed of 30 children, whose motor development was within norm limits. Results. A delayed motor development in children corresponds with spatial hearing impairment. Children have a particular problem with locating sounds coming from above and below the head. The main factors contributing to abnormal auditory perception include: delayed physical development, reduced muscle tone and age.

Conclusions. Our study demonstrates a significant relationship between pathological tonus and auditory perception disorders. Abnormal auditory reactions could be observed in children with pathological tonus. This, in turn, affects the development of spatial hearing. A relationship has been found between children's age and spatial hearing. Children under 40 weeks of age tended to have worse hearing reactions than older children.

Key words: directional hearing, auditory perception, sound source localization, delayed motor development, proper motor development.

Pawlukowska W, Siwczak K, Szylińska A, Turoń A, Rotter I. The impact of muscle tone on the development of auditory perception - research orientation. Fam Med Prim Care Rev 2017; 19(4): 382-386, doi: https://doi.org/10.5114/fmpcr.2017.70812.

\section{Background}

Auditory perception is a complex process of organizing sensory information received by the brain through the auditory system. The information is subsequently processed and used in thought processes and speech [1]. Localization of a source of sound refers to the ability to establish the actual direction of an incoming sound and to assess the distance from its source. The sensation that forms outside the head of a subject has been termed the externalization of a sound image [2]. Auditory perception also refers to the ability to receive, recognize, discriminate and interpret sounds. In order to properly determine the source of a sound in space requires taking into account three planes: horizontal, medial and frontal. All these planes cross in the middle of the head, marking the point 0.0 on the coordinate system. The horizontal plane passes through the lower edges of the orbital cavities and the lower edges of the external auditory foramens. The frontal plane is perpendicular to the horizontal one, whereas the medial plane lies perpendicularly to the other two planes [3]. Sounds coming from the front are localized more easily than those approaching from the back or the side. Directional hearing precedes the development of speech reception, pure tone or noise, which is why some children either develop distorted speech or do not develop speech at all. Wyatt et al. found that a dysfunction of one sense adversely impacts the other senses. He observed in a group of deaf subjects a dete- rioration of motor and visual-motor fitness [4]. The finding led to the formulation of a hypothesis that motor disorders affect the development of auditory perception. This aspect of human development is important in the context of primary healthcare. The role of a family doctor is vital, as he or she is the first to spot any abnormalities and refer the child to a specialist and for further examinations [5]. Early diagnosis and prescribing relevant therapy to support auditory perception enable harmonious development of speech. Moreover, auditory deficits, in particular concerning tinnitus, are associated with impaired visual and somatomotor functions. It has been shown that certain features of sound may be distorted in patients with abnormal voltage within the muscles of the neck, head and limbs [6-18].

\section{Objectives}

Auditory perception in children affected with pathological muscle tone, including a comparison of spatial localization in children without tonus abnormalities. The influence of age and gender on auditory reactions in children with and without pathological muscle tone.

\section{Material and methods}

The studied group consisted of 29 (100\%) subjects, made up of 8 females (28\%) and 21 males (72\%), all afflicted with tonus 
pathology. The group were recruited from the Children's Rehabilitation and Therapy Center 'Corecta' in Szczecin, as well as Department of Pediatrics, Endocrinology, Diabetology, Metabolic Diseases and Cardiology of Developmental Age of the Autonomous Public Clinical Hospital at Unii Lubelskiej St. in Szczecin. The children were aged between 30 and 116 weeks (mean age 44.6 weeks) and divided into subgroups according to their levels of motor development: 20 (68\%) of the children suffered from hypotonia of central origin caused by hypoxia ( 3 subjects) and premature birth (17 subjects). The remaining 9 (32\%) were hypertonic due to perinatal damage ( 5 subjects) and hypoxia ( 4 subjects). The eligible children were with moderate or severe disorders of muscle tone. The study did not take into consideration children with a mild decrease in muscle tone. Evaluation of muscle tone and motor development was performed by a child neurologist and a specialist in physiotherapy. A physical examination and a test for neurological symptoms in order to evaluate muscle tone were performed on the children. The children underwent Bobath and Voida rehabilitation therapies, which lasted between 30 and 116 weeks.

The control group was composed of 30 children whose motor development was within norm limit. The group comprised 17 females (57\%) and 13 males (43\%), aged between 33 and 118 weeks (mean age 55 weeks). Some of the children were under the care of a pediatrician in the outpatient clinic of the Pomeranian Medical University. The treatment group and the control group came from the West Pomeranian Province and were of the same age. All groups were with hearing disorders. Children in the control group were found to have abnormal muscle tension.

The hearing test carried out by means of the auditory brainstem response test (ABR) revealed that none of the children participating in the study suffered from any hearing disorders.

Screening for sound localization disorders was conducted with a calibrated rattle manufactured by Manchester Rattle, emitting sounds at a frequency of $5 \mathrm{kHz}$. These are standard tools normally used for testing hearing in children.

During the test, the child was sitting on their parent's lap, with their back to the examiner, who, from a distance of one meter, was delivering sounds using the rattle positioned at the level of the ear, on the left and on the right side, as well as above and below the level of the head.

The results were considered normal when the examined child was looking for the source of the sound in the correct direction. Lack of such a reaction meant an abnormal result. We also designed an original questionnaire with 20 questions concerning the children's gender, age and date of birth, the number of previous pregnancies of the mother and the course of the last one, labor and the child's Apgar score. Parents of the children with retarded motor development were questioned about the length of the rehabilitation therapy and the motives for choosing it for their children.

The study was approved by the Pomeranian Medical University Commission of Ethics - Resolution no. KB-0012/89/02/17.

\section{Statistical analysis}

Descriptive statistics were used in data analysis. The Shapiro-Wilk test was applied to check the normality of distribution of quantitative variables. Since the tested quantitative variables deviated from normal distribution, the analysis was carried out by means of the non-parametric Mann-Whitney $U$ test. To assess nominal variables in children with or without disorders, a chi-squared test was employed. Spearman's ranks enabled the assessment of the correlation between qualitative variables.

Effect size for contingency tables was used for the analysis of the relative risk and the odds ratio. The results were considered statistically significant at $p<0.05$. Licensed STATISTICA 12 (StatSoft, Inc. Tulsa, OK, USA) software was used for performing the calculations.

\section{Results}

\begin{tabular}{|c|c|c|c|c|}
\hline & & $\begin{array}{l}\text { Children with } \\
\text { pathological } \\
\text { tonus } \\
(n=29) \\
\end{array}$ & $\begin{array}{l}\text { Children with } \\
\text { normal tonus } \\
(n=30)\end{array}$ & $p$ \\
\hline \multicolumn{2}{|l|}{ Female } & $8(27.59 \%)$ & 17 (56.67\%) & \multirow[t]{2}{*}{0.02} \\
\hline \multicolumn{2}{|l|}{ Male } & 21 (72.41\%) & 13 (43.33\%) & \\
\hline \multicolumn{2}{|c|}{ Natural childbirth } & $10(34.48 \%)$ & $14(46.67 \%)$ & \multirow[t]{2}{*}{0.34} \\
\hline \multicolumn{2}{|c|}{ Caesarean section } & 19 (65.52\%) & $16(53.33 \%)$ & \\
\hline \multirow[t]{2}{*}{ Pregnancy } & normal & 22 (75.86\%) & 23 (76.67\%) & \multirow[t]{2}{*}{0.94} \\
\hline & disturbed & 7 (24.14\%) & $7(23.33 \%)$ & \\
\hline \multirow{2}{*}{$\begin{array}{l}\text { Burden of } \\
\text { perinatal }\end{array}$} & yes & $11(37.93 \%)$ & 9 (30.00\%) & \multirow[t]{2}{*}{0.52} \\
\hline & no & $18(62.07 \%)$ & $21(70.00 \%)$ & \\
\hline \multicolumn{2}{|c|}{ Week of birth } & $37.5 \pm 3.3$ & $39.2 \pm 1.4$ & 0.03 \\
\hline \multicolumn{2}{|l|}{ Apgar score } & $9.5 \pm 0.9$ & $9.7 \pm 1$ & 0.21 \\
\hline \multicolumn{2}{|c|}{ Age [weeks] } & $42.1 \pm 28.4$ & $46.9 \pm 18.2$ & 0.06 \\
\hline
\end{tabular}

Table 2 illustrates the relationship between auditory reactions to sounds delivered from above and below the head, as well as from the level of the left and the right ear in children with pathological and normal tonus. Tests of auditory perception, including spatial localization, revealed a dysfunction of the right ear in 4 (6.8\%) children afflicted with tonus abnormalities, whereas no such dysfunction was observed in patients with physiological tonus $(p=0.03)$.

The relative risk of the occurrence of dysfunction of the right ear in people with pathological muscle tone is twice as high as the risk of the dysfunction occurring in people without tonus disorders ( $R R=1,833)$. When the sound was delivered

\begin{tabular}{|c|c|c|c|c|c|c|c|}
\hline \multirow{2}{*}{\multicolumn{3}{|c|}{ Variables }} & \multicolumn{2}{|c|}{$\begin{array}{l}\text { Children with pathological tonus } \\
(n=29)\end{array}$} & \multicolumn{2}{|c|}{$\begin{array}{l}\text { Children with normal tonus } \\
(n=30)\end{array}$} & \multirow[t]{2}{*}{$p$} \\
\hline & & & $n$ & $\%$ & $n$ & $\%$ & \\
\hline \multirow{8}{*}{$\begin{array}{l}\text { Auditory perception in } \\
\text { the context of spatial } \\
\text { localization }\end{array}$} & \multirow[t]{2}{*}{ right ear } & normal & 25 & 42.4 & 30 & 50.8 & \multirow[t]{2}{*}{0.03} \\
\hline & & disturbed & 4 & 6.8 & 0 & 0 & \\
\hline & \multirow[t]{2}{*}{ left ear } & normal & 27 & 45.8 & 30 & 50.8 & \multirow[t]{2}{*}{0.14} \\
\hline & & disturbed & 2 & 3.4 & 0 & 0 & \\
\hline & \multirow[t]{2}{*}{ above } & normal & 9 & 15.3 & 21 & 35.5 & \multirow[t]{2}{*}{0.002} \\
\hline & & disturbed & 20 & 33.9 & 9 & 15.3 & \\
\hline & \multirow[t]{2}{*}{ below } & normal & 10 & 16.9 & 23 & 38.9 & \multirow[t]{2}{*}{0.001} \\
\hline & & disturbed & 19 & 32.3 & 7 & 11.9 & \\
\hline
\end{tabular}


from overhead, abnormalities in $20(70 \%)$ of the children with tonus disorder were found compared to $9(30 \%)$ of the children with normal tonus. Children with pathological tonus are 5 times more likely to develop disturbed auditory perception of overhead sounds $(O R=5,185)$. The analysis of lower spatial localization produced similar results $(O R=6,243)$; here, the abnormalities were reported in as many as $19(66 \%)$ of the children with abnormal muscle tone. By comparison, only 7 (23\%) of the healthy children displayed problems with localization of a sound sent from below.

Table 3 illustrates the relationship between age, development and reactions to sounds delivered laterally (right and left ear) and from above and below the head in children with pathological and normal tonus. The strongest negative correlation was found between the children's age and disturbed auditory reactions to a sound whose source was placed overhead, as well as to a sound delivered laterally from the right side.

Younger subjects with pathological tonus proved worse at reacting to sounds approaching from below the head and towards the right ear than their healthy counterparts. They were also less effective in localizing sounds emitted from above and below the head, as well as those approaching the right ear.

\begin{tabular}{|c|c|c|c|}
\hline Pair of variables & $n$ & $R$ & $p$ \\
\hline Child's age [weeks] \& right ear & 59 & -0.36 & 0.005 \\
\hline Child's age [weeks] \& left ear & 59 & -0.26 & 0.048 \\
\hline Child's age [weeks] \& above & 59 & -0.40 & $<0.001$ \\
\hline Child's age [weeks] \& below & 59 & -0.24 & 0.071 \\
\hline
\end{tabular}

\section{Discussion}

Auditory perception, and sound localization in particular, is a higher auditory function. It is by all means essential for the proper development of a human organism and its motor functions. Any abnormalities occurring in the development of those skills might seriously impair a child's development, which can consequently have an adverse effect on their future life.

Our study demonstrates a relationship between children's pathological tonus, their age and auditory perception.

No scientific publications concerning auditory perception in children with pathological tonus have been found. A number of existing studies focused on an analysis of the ability to localize sound in space. The researchers described methods of evaluation of directional hearing (Polizer, Preyer, Wertheimer, Muir) or contemplated babies' ability to localize a source of sound [3, 19, 20]. An abnormality present in at least one of the higher auditory functions, such as directional hearing, sound discrimination or time analysis of a sound signal, provides a basis for diagnosing disturbances in the functioning of central auditory processing in children [21].

Although Kułakowska worked on a description of motor development and factors that can adversely affect it, she did not take hearing disorders into account [22-24]. Krawański [25] and Dziedzic and Rempelewicz [26], studying a cohort of children with hearing impairment, found that their motor development was delayed in comparison with children that could hear well. Szkiełkowska et al. [27] and Myklebust [28] noticed that physical development correlates with proper hearing and, consequently, speech development.

Our research proves the existence of a relationship between pathological muscle tone and impaired auditory perception in children. It can be concluded that auditory and motor functions significantly interact with each other during the first months of life. This hypothesis can be supported by the fact that the gradually increasing diversification of a child's movements (turning sideways, sitting and getting up to the vertical), where tonus plays an important role, runs parallel to the development of auditory functions (lateral, up and down localization).

There are a host of circumstances affecting proper physical development. According to Kułakowska, gradual understanding of the body schema is very intensive in children in the first months of life and depends on certain factors, such as time, in which particular structures within the central nervous system mature as well as all the sensations resulting from the impact of the environment [22]. Postural tonus forms and develops owing to frequent changes in the position of the body. New sensory stimuli are provided, and the medial line becomes evident, which affects the process of lateralization. Proper tonus and reception of proprioceptive stimulation are other vital prerequisites for lateralization and, consequently, a normal body schema.

The development of lateralization is determined by the environment a child grows in, overall development, as well as innate patterns. Delayed lateralization can be observed in children with neurodevelopmental disorders [29]. Ritzke et al. found that deaf children displayed abnormal development of the rib cage and posture. Also, other studies proved that impaired hearing indirectly affects motor fitness and physical activity [30]. The relationship between impaired hearing and motor fitness and physical activity was not confirmed by Gesell and Amatura, even though they did find a correlation between motor skills and the development of cognitive functions in children during their babyhood [31]. Myklebust also noticed that hearing impairment impacts physical development. He pointed to the existence of a relationship between distorted physical development and a type and etiology of deafness. He argues that the components of physical fitness that are particularly affected by lack of hearing are: coordination, movement speed and balance [28].

The correlation between muscle tone and physical development and auditory localization was also confirmed by Szkiełkowska et al., who demonstrated in her research that in $27 \%$ of children with delayed speech development corresponded with pathological muscle tone in early childhood.

It is worth noting that hearing impairment frequently results in delayed speech development, so it is essential that children with a motor disorder undergo thorough hearing testing [27]

Auditory perception develops with age, and proper growth stimulates the improvement of auditory perception in 3-month-old babies. The process is attributed to increased motor activity and, in particular, better performance of head movements. At this time, auditory reactions are becoming more distinct for a child [32]. Another author points out that it is not before a child turns 5 months old that they begin to turn the head towards a sound, listen intently or try to localize the source of a sound coming from the side. A 9-month-old infant already has the ability to localize sounds emitted from the side, above or below the head [33]. Normalization of multisensory connections is determined by the frequency at which a certain experience occurs. The hearing ability that babies develop proves that stimulating the hearing organ must be accompanied by physical exercise [32].

It is worth bearing in mind that age is a factor that must be taken into consideration while assessing a child's growth. Each sense and organ takes time to develop. Children aged between 1 and 4 months are still unable to localize a sound, but those who are a few months older (4-8) will have already acquired the ability. They also begin to imitate actions that they see around them. The same applies to sounds. Babies gradually try, in their own way, to mimic the sounds they hear. 8-12 months of age marks the time when children's actions are becoming intentional and thoughtful [34]. It is important that each sense develops normally. Abnormalities in the development of one function can have a negative influence on the development of the entire body. 
Our study also demonstrated a correlation between age and auditor perception. Older children proved better at localizing a source of sound, which corresponds with the current state of research.

\section{Limitations of the study}

If our group was greater, we would more accurately be able examine the problem of auditory perception in children with abnormal muscular tension. Our studies only signal the problem and provide an introduction to further work.

\section{Conclusions}

Our study demonstrates a significant relationship between pathological tonus and auditory perception disorders. Abnormal auditory reactions could be observed in children with pathological tonus. This, in turn, affects the development of spatial hearing. A relationship has been found between children's age and spatial hearing. Children under 40 weeks of age tended to have worse hearing reactions than older children. Exercise to improve the development of spatial hearing seems to be the appropriate management of disturbed muscle tension in children.

Source of funding: This work was funded by the authors' own resources.

Conflict of interest: The authors declare no conflict of interests.

\section{References}

1. Przyrowski Z. Centralne zaburzenia słuchu w teorii integracji sensorycznej. Biuletyn SI 2006; 3: 1-9 (in Polish).

2. Plenge G. On the differences between localization and lateralization. J Acoust Soc Am 1974; 56(3): 944-945.

3. Niewiarowicz M, Czajka J. Lokalizacja źródeł dźwięku. Podstawy teoretyczne oraz wyniki badań eksperymentalnych. Postępy w Chirurgii Głowy i Szyi 2005; 1: 25-42 (in Polish).

4. Wyatt J, Rizzo JF. Prospects for a visual prosthesis. Neuroscientist 1997; 3: 251-262

5. Czachowski S, Buczkowski K. Empatia a holistyczne postrzeganie pacjentów przez lekarza rodzinnego. Fam Med Prim Care Rev 2007; 9(3): 387-390 (in Polish).

6. Levine RA. Somatic modulation appears to be a fundamental attribute of tinntus. In: Hazell JPW, ed. Proceedings of the Sixth International Tinnitus Seminar. London: The Tinnitus and Hyperacusis Center; 1999: 193-197.

7. Sanchez TG, Guerra GCY, Lorenzi MC, et al. The influence of voluntary muscle contractions upon the onset and modulation of tinnitus. Audiol Neurootol 2002; 7(6): 370-375.

8. Sanchez TG, Lima AS, Brandao AL, et al. Somatic modulation of tinnitus: test reliability and results after repetitive muscle contraction training. Ann Otol Rhinol Laryngol 2007; 116(1): 30-35.

9. Coad ML, Lockwood A, Salvi R, et al. Characteristics of patients with gaze-evoked tinnitus. Otol Neurotol 2001; 22(5): 650-654.

10. Baguley DM, Phillips J, Humphriss RL, et al. The prevalence and onset of gaze modulation of tinnitus and increased sensitivity to noise after translabyrinthine vestibular schwannoma excision. Otol Neurotol 2006; 27(2): 220-224.

11. Sanchez TG, Pio MRB. Abolição de zumbido evocado pela movimentação ocular por meio de repetição do deslocamento do olhar: um método inovador. Arq Otorhinolaryngol 2007; 11: 451-453.

12. Rocha CACB, Sanchez TG. Myofascial trigger points: another way of modulating tinnitus. Prog Brain Res 2007; 166: $209-214$.

13. Rocha CACB, Sanchez TG, Siqueira JTT. Myofascial trigger points: a possible way of modulating tinnitus. Audiol Neurootol 2008; $13(3)$ : 153-160.

14. Cacace AT, Cousins JP, Parnes SM, et al. Cutaneous-evoked tinnitus. II. Review of neuroanatomical, physiological and functional imaging studies. Audiol Neurootol 1999; 4(5): 247-257.

15. Sanchez TG, Marcondes RA, Kii MA, et al. A different case of tinnitus modulation by tactile stimuli in a patient with pulsatile tinnitus. Presented at the Second Meeting of the Tinnitus Research Initiative. Monaco; 2007: 21-23.

16. Møller AR, Rollins PR. The non-classical auditory pathways are involved in hearing in children but not in adults. Neurosci Lett 2002; 319(1): 41-44.

17. Cullington H. Tinnitus evoked by finger movement: brain plasticity after peripheral deafferentation. Neurology 2001; 56(7): 978-979, doi: http://dx.doi.org/10.1212/WNL.56.7.978.

18. Pinchoff RJ, Burkard RF, Salvi RJ, et al. Modulation of tinnitus by voluntary jaw movements. Am J Otol 1998; 19(6): 785-789.

19. Nordlund B. Physical factors in angular localization. Acta Otolaryngol 1962; 54: 75-93.

20. Gromnicki M, Narożny W, Kuczkowski J, et al. Kąt ostrości słyszenia kierunkowego u chorych po przebytym nagłym niedosłuchu czuciowo-nerwowym. Otolaryngologia 2013; 12(3): 130-134 (in Polish).

21. Włodarczyk E, Szkiełkowska A, Skarżyński H, et al. Zaburzenia artykulacji u dzieci ze współistniejącymi zaburzeniami przetwarzania słuchowego - efekty terapii słuchowej. Otolar Pol 2011; 65(5): 339-344 (in Polish).

22. Kułakowska Z. Wczesne uszkodzenie dojrzewajqcego mózgu - od neurofizjologii do rehabilitacji. Lublin: Wydawnictwo Folium; 2003: 97 (in Polish).

23. Wasilewski W. Wczesne wspomaganie rozwoju ruchowego dziecka niepełnosprawnego. 1-14 [cited 15.08.2016]. Available from URL: https://womgorz.edu.pl/files/file/pracownia_psychoedukacji/w._wasielewski_wcz._wspom_r._r.pdf (in Polish).

24. Senderski A. Rozpoznawanie i postępowanie w zaburzeniach przetwarzania słuchowego u dzieci. Otolaryngologia 2014; 13(2): 11-81 (in Polish).

25. Krawański A. Ocena rozwoju fizycznego młodzieży głuchej i normalnej. Warszawa: Wydawnictwo WFiS; 1974 (in Polish).

26. Dziedzic J, Rempelewicz J. Kultura w szkołach i zakładach dla niewidomych i niedowidzqcych. Warszawa: Wydawnictwa Szkolne i Pedagogiczne; 1980 (in Polish).

27. Szkiełkowska A, Wodarczyk E, Senderski A, et al. Ocena procesów przetwarzania słuchowego u dzieci z dyslalią. Foniatria i audiologia 2009; 63(1): 55-57 (in Polish).

28. Myklebust HR. The psychology of deafness. New York: Grune and Stratton; 1965.

29. Paczkowska A, Szmalec J, Zielonka D. Wykrywanie problemów związanych z nieustaloną lateralizacją i możliwości im przeciwdziałania dla prawidłowego rozwoju dziecka. Hygeia Public Health 2014; 49(3): 531-535 (in Polish).

30. Ritzke L. Pojemność życiowa płuc, rozmach oddechowy oraz zmysł równowagi jako problem rewalidacji dzieci głuchych w wieku szkolnym. Szkoła Specjalna 1975; 3: 25-33 (in Polish).

31. Gesell A, Amatura C. Developmental diagnosis. New York: Paul B. Hoeber, Inc.; 1975.

32. Karasek-Sajbor B. Rozwój percepcji słuchowej w pierwszym roku życia dziecka [cited 15.08.2016]. Available from URL: http://www. logopedia.pl/index2.php?option = com_content\&do_pdf = 1\&id = 524 (in Polish). 
33. Góralówna M, Hołyńska B. Rehabilitacja małych dzieci z wadq słuchu. Warszawa: Wydawnictwo Lekarskie PZWL; 1998.

34. Piek JP. Infant motor development. Champaign, IL: Human Kinetics; 2006.

Tables: 3

Figures: 0

References: 34

Received: 09.12.2016

Revised: 13.02.2017

Accepted: 06.03.2017

Address for correspondence:

Aleksandra Szylińska, MSc

Zakład Rehabilitacji Medycznej i Fizjoterapii Klinicznej PUM

ul. Żołnierska 54

71-252 Szczecin

Polska

Tel.: +48 509 560-808

E-mail: aleksandra.szylinska@gmail.com 